\title{
Same, same but different? Women's experiences with gender inequality in Brazil
}

\section{Introduction}

Despite decades of research and debates, gender inequality remains a worldwide issue and one that "appears to be at the forefront of the global humanitarian agenda" (Joshi et al., 2015, p. 1459). There has been progress in female representation and an increase in gender diversity, but a lack of understanding remains as women have achieved little progress in reaching top management and leadership positions (Madsen and Scriber, 2017). On the positive side, women are completing undergraduate degrees at a higher rate (Burke and Vinnicombe, 2013); but more often than not, they earn less than men for comparable jobs and tend to be over-represented in casual or unpaid roles (Beed et al., 2011; Cook and Glass, 2014). Researchers have dedicated more than 3000 papers since 1970 to try to understand the factors that underpin gender inequality (Eagly and Heilman, 2016). Of those, $38 \%$ were published after 2010 , revealing growing interest in the topic.

Gender scholars have emphasized the need for more theorizing and research with a "less West-centric stance" (Holden et al., 2015, p. xlvi) focusing on other geographical regions such as Latin America, which is "sorely underrepresented" (Madsen and Scribner, 2017, p. 243). In Brazil, the largest country in South America, gender has been addressed in the literature from a variety of fields, with publications targeting gender relations at work (often from the harassment/abuse perspective), followed by gender and sexuality, and gender violence (Araújo and Lombardi, 2013; Degraff and Anker, 2015; Gonçalves, Perez and Wajnman, 2016).

Brazil has gone through significant changes in the workplace scenario due to demographic forces, economic shifts and technological advances. There has been an observable increase in women's participation in the labor market from 39.6\% in 1993 to 44\% in 2016 (Bruschini, 2007; IPEA, 2016). Nonetheless, females are still responsible for the majority of non-paid activities at home, working on average 7.5 hours a week more than men in total (IBGE, 2016; IPEA, 2016). In addition, women have a greater role in family leadership, with female heads of households increasing from approximately $20 \%$ in 1986 to more than $40 \%$ thirty years later (Barros et al., 1997; IBGE, 2016; OlivasLujan et al., 2009). 
Gender and diversity in Brazil have often been examined from a macro or meso approach, hence, from a country or organizational perspective. For example, Jabbour and colleagues (2011) studied diversity management in organizations through a series of case studies and Fleury (1999) observed the management of cultural diversity in leading Brazilian firms. While the organizational perspective is crucial to the field, the present article is unique in that it aims to give voice to the individual experiences of female workers within that organizational context. Furthermore, the study targets a country that has been cited as a potential powerhouse while presenting numerous idiosyncrasies - so that one wonders whether "Brazil is making progress or inequality?" (Corrigan, 2015).

The overarching objective of this paper is not only to provide individual accounts of how gender inequality is experienced, but also to uncover the content of shared discourses that characterize the female experience at organizations in Brazil nowadays. These discourses include perceptions of:

- gender issues, such as discrimination at work;

- organizational practices, particularly human resources (HR);

- and the overall experience of being a working woman at work and at home.

Study participants belonged to organizations situated in Rio de Janeiro and São Paulo, the Southeastern region of Brazil, which is the most developed region in the country and where the majority of organizations have headquarters (Sheng and Carrera Junior, 2016). The interpretive approach chosen allows the researchers to address issues of description, interpretation, and explanation (Lee, 1999), while uncovering deeper processes and mechanisms in individuals (Bluhm et al., 2011). The following sections provide further contextual and theoretical background for the study.

\section{Gender in Brazil}

With a population of over 200 million, Brazil has undergone substantial turmoil in the last few years. Following a period of extreme prosperity in the early 2000s as one of the world's emerging economies, the country has been facing serious economic and political issues recently. Investment into deepwater oil, although promising, led to excessive debt, which was worsened by the collapse of oil prices (Galbreath, 2017). Moreover, the economy plummeted further with corruption scandals (primarily Operation Carwash) that encapsulates people at the very top of businesses as well as politicians and 
high-ranking civil servants in most government branches (Bonifácio and Ribeiro, 2016; Galbreath, 2017).

With regard to gender, the Gender Inequality Index (GII) provides a broader picture of the current scenario in the country. The GII is an aggregate intended to reflect gender-based inequalities in the following dimensions - reproductive health, empowerment, and economic activity (Hausman, 2014). It can be interpreted as the loss in human development due to inequality between female and male achievements in the three GII dimensions. According to the GII, Brazil ranks 92 out of 159 countries in the 2015 index. In Brazil, $10.8 \%$ of parliamentary seats are held by women, and $59.1 \%$ of adult women have reached at least a secondary level of education compared to $55.2 \%$ of their male counterparts. Female participation in the labor market is $56.3 \%$ compared to $78.5 \%$ for men (HDR, 2016).

Women's status in Brazil has been changing over the last several years with public policies and agencies that were developed and included in the government agenda in an effort to promote gender equality (Araújo and Lombardi, 2013; Moreira, 2016; Olinto and De Oliveira, 2016). For example, the Brazilian 1988 Constitution led to the establishment of the National Agency for Women's Rights, the Regional Agencies for Women, and the Police Station Specialized in Women. In 2004, the National Plan of Policies for Women was created to address gender discrimination and to foster educational policies from an equality perspective. In 2006, the first and only bill against domestic violence was enacted into law (Moreira, 2016).

A Pew Research Study on global attitudes released in September 2010 revealed that, generally speaking, Brazilians espouse a modern discourse of pro gender equality. The country's majority supports women's right to work even in tough economic times $(63 \%)$ as well as consider marriage more satisfying when both spouses work, share household tasks and responsibilities for children (Pew Research Center, 2010). While discourse support for gender equality is high, many believe that there is still progress to be made with almost a half of participants thinking that men, in practice, have a better life than women (Pew Research Center, 2010).

At home, women are more likely to assume the largest share of responsibility in terms of household chores and child-rearing (Casper et al., 2011). More often than not, women contribute to the household income through informal jobs (Araújo and Lombardi, 
2013; Gonçalves et al., 2016; Sorj, 2004). Informal jobs are those that bypass labor regulations, that is, employees do not use the official work document that registers all employment contracts the individual has signed. It is the document that guarantees access to a variety of employee rights (MTE, 2016). However, data shows some improvement, as more workers are engaged in formal arrangements, and the majority of this growth is attributed to women. (IBGE, 2010, 2016). For example, there was a growth in the working population of about 25\% between 2003 and 2014. At the same time, the number of individuals with formal jobs went from $39,7 \%$ to $59,6 \%$ in that period (IBGE, 2016).

From a meso perspective, a conscientious move towards organizational diversity in Brazil became more noticeable only in the 1990s as a consequence of minority movements that brought discrimination and racial diversity to the agenda (Jabbour et al, 2011). Diversity can be defined quite widely as "a multifaceted, contextual and multidimensional construct" (Gotsis and Kortezi, 2013, p. 948). As a central theme, it emerged in the 1960s in the United States with the Civil Rights movement that fought for racial equality (Agócs and Burr, 1996; Thomas and Ely, 1996). Debates were originally centered on human rights and anti-discrimination. Subsequently, in the 1980s, the focus shifted to diversity management in the workplace through a more positive and dominant rhetoric (Zanoni et al., 2010). These discussions were often tied to the demographic imperative, that is, the continuous transformation of the workforce profile due to demographic and economic forces such as labor market changes and globalization (Cox and Blake, 1991; Ivancevich and Gilbert, 2000). In contrast to the government-mandated affirmative action programs, diversity management is initiated by the organization and focuses on maximizing the benefits of a diverse workforce. It can be described as a targeted effort by the organization to value all employees and as an attempt to learn how to deal with differences, while guaranteeing employees' inclusion in company networks and providing access to company resources and programs (Agócs and Burr, 1996; Gilbert et al., 1999).

Worldwide, interest in diversity has been met with increased research (Theodorakopoulos and Budhwar, 2015), yet scholars question whether the shift in discourse from affirmative action (and equal opportunity) to diversity management has been followed by practice (Tatli, 2010). Authors have pointed out that diversity efforts in organizations may be "rhetorically-based management fashion" (Oswick and Noon, 2014, p. 24) or "old ideas in new skins" (Crenshaw, 2011, p. 1315), in that organizations 
have been more concerned with compliance rather than leveraging the benefits of a diverse workforce (Nkomo, 2013).

In Brazil, research from a diversity management standpoint is slim (Jabbour et al., 2011). The studies that have been conducted in the country (e.g.: Jabbour et al., 2011; Vasconcellos, Borges-Andrade, Porto and Fonseca, 2016) have targeted the organizational level and show that a vast majority of firms tend to focus on following state regulations rather than initiating the implementation of diversity policies. More specifically, companies operating in Brazil have dealt with diversity by purposefully recruiting and selecting diverse employees and promoting activities internally such as conferences and meetings (Jabbour et al., 2011). This is evidenced by Jabbour and colleagues' (2011) research which found that of all the organizations studied only one focused on women, while most targeted disabled individuals - which is a pressing legal mandate and one of the most difficult quota requirements to satisfy. Overall, in most HR areas, diversity included, Brazil seems to be lagging behind global trends (Tanure et al., 2010) and gender inequality persists (Lazzaretti et al., 2013). In fact, authors suggest that changes in the HR field are mainly a consequence of the stronger presence of multinationals and the global policies implemented by those when they operate in Brazil (Bardoel, 2016; Tanure et al., 2010). These changes are a possible outcome from what has been named glocalization. Glocalization is defined as the adaptation of international products around the particularities of a local culture in which they are sold (Heinrich, 2012), and management scholars have been using it to describe the process of adapting policies, procedures and so on related to the way a company does business.

\section{Theoretical Framework}

While diversity influences the organizational context, gender studies require a more profound consideration of the society as a whole. This is particularly critical for the Brazilian setting since gender roles do not necessarily reflect the newer economic and political realities of the country. This cultural lag may be due to its tradition as a maledominated society and the presence and dissemination of machismo and marianismo (Dieckman et al., 2005). Since Portuguese colonizers, men have been identified with authority and strength, while women have been associated with weakness and subservience (Margolis, et al., 2001). As an example, even though women acquired the right to vote in 1932, it was only in the 1960s that they conquered the right to work 
without requiring the previous permission from their husbands (Narvaz and Kohler, 2006).

Machismo and marianismo are often examined as extensions of gender roles, predominantly in Latin cultures (Torres et al., 2002) and are key to understanding Brazilian gender relations (DeSouza and Baldwin, 2001). They are complex phenomena that act as "cultural scripts that are embedded in the culture with different degrees of intensity" (Moreno, 2007, p. 341). Machismo relates to male over female power, focusing on strength, sexuality, violence and aggression (Félix-Ortiz et al., 2001), whereas marianismo refers to female piety, sacrifice, and virtue (Baldwin and De Souza, 2001). Marianismo, or the other face of machismo, gets its name from the image of the ideal woman inspired by the Virgin Mary (Barcinski et al., 2013). This notion reproduces traditional roles, particularly with regard to women's caring responsibilities and domestic life. Authors have emphasized the importance of examining machismo and marianismo beyond a negative lens (Barcinski et al., 2013). For example, machismo may be associated with dignity, pride, tenacity (Mirandé, 1985), and marianismo may be linked to control rather than simply subordination, particularly in the privacy of family life (Chaney, 1979).

Gender dynamics may also be examined from the perspective of feminist theory (Wyrod, 2008) and the ways in which women negotiate the world, which differ among those in diverse contexts (cultural, social, political) and with diverse personal characteristics (age, education, sexual orientation). The main point feminist theorists have stressed about gender inequality is that it is not neither just an individual matter nor a purely corporate issue to be dealt with. Instead, gender inequality is deeply ingrained in the structure of societies, thus built into the organization of marriage and families, work and the economy, politics, religions, the arts and other cultural productions, as well as into the very language we speak (Ferree, 1990; Risman, 2004). A strand of feminist theorists suggests an emphasis on development feminism, which is particularly suitable to gendered analyses in developing countries. Development feminism addresses the political issue of women's rights versus national and cultural traditions, which is a conundrum globally (Wyrod, 2008) and particularly relevant to this research.

In the present study, we hoped to extend knowledge by combining the theoretical concepts described above in feminist theory and cultural traditions such as marianismo and machismo. Given that gender inequality is ingrained in the fabric of society and that it is often prominent in developing country cultures, we believe an exploratory study has 
the potential to unveil hidden meanings, beliefs, and assumptions. In particular, this format allows us to observe the impact of culture and gender roles as they relate to machismo and marianismo in the shared discourses of the women who experience work and life within the Brazilian context. Through their accounts, we attempt to gauge whether Brazil has made real advances with regard to gender equality.

\section{Method}

The present study examined the experiences of professional women currently working in Brazilian organizations. Those are critical locations for the investigation of inequalities because much of the inequality found in society originates in the workplace (Acker, 2006). Organizations may also be where attempts are made to alter patterns of inequality, particularly through a discourse of diversity and inclusion (Oswick and Noon, 2014).

The authors used the content analysis method to identify patterns in the substance and form of communication (Yang, 2008). It is a qualitative method that allows researchers to describe a phenomenon without using previously defined categories - so that themes and categories emerge from the data (Hsieh and Shannon, 2005). With this method, the researcher gets immersed in the whole by reading the data several times (Tesch, 1990). This process must be followed by an analysis of words and the way they represent thoughts, and a systematic process of coding and extracting information (Miles and Huberman, 1994; Rubin and Rubin, 2011). Afterwards, codes have to be labeled so that they can be grouped into categories or topics organized in a hierarchical manner (Hsieh and Shannon, 2005; Morse and Field, 1995). To ensure rigor, codes and categories were defined. Coding was conducted separately by the researchers who compared results subsequently.

The researchers chose in-depth interviews in a semi-structured format so that participants could direct the conversation flow. The recruitment of potential participants took place through the researchers' personal contacts, partnerships with academic institutions and HR-related organizations, and posts in social media such as LinkedIn. The sample consisted of 26 Brazilian female professionals who held positions as analysts, managers, or directors in the metropolitan areas of Rio de Janeiro and São Paulo in the Southeastern region of Brazil. This region concentrates the majority of organizations in Brazil. The sample included a balanced number of interviewees from multinational 
companies operating in Brazil as well as from domestic organizations. All participants had higher education, with at least a bachelor's degree in a variety of areas such as business, communications, political science, engineering, and psychology. Participants had been working at their current organization for at least one year and had at least four years of work experience. The number of interviews was considered satisfactory as there was no significant new information to be added to the study at that point, as the content analyzed showed repetition in themes.

Interviews took place at the location where the participant worked, usually in a meeting room. Interviews were conducted in Portuguese by one of the authors, with lengths that varied between 60 and 150 minutes. Interviews were digitally recorded and later transcribed.

\section{Findings}

The answers provided by participants led to themes that were grouped into four categories. It is important to note that there were no observable differences between individual experiences and perceptions of women who worked in multinational or domestic organizations. Moreover, the various positions held by women at their respective organizations suggest comparable individual experiences and perceptions.

With regard to gender issues perceived and experienced at work (Table 1), the themes that surfaced from this category focused on (a) covert discrimination, (b) the impact of organizational culture, and (c) the experience of discrimination as something that happens to others.

Overall, the majority of participants stated not having experienced inequality at their workplace and that differences detected were not considered gender issues but related to the role each individual has in the organization. Issues with gender pay differences were also not mentioned by any of the women interviewed. Participants stated that pay was set before the hiring process so that it was associated with the individual's position and role rather than gender.

However, when asked whether participants observed inequality with coworkers, most indicated that there were indeed issues related to gender. From the interviewer's perspective, it seemed that participants were quite cautious when addressing 
discrimination. If respondents stated they had noticed it in their work environment, they tended to attribute it to another woman rather than personalizing it. One participant discussed what happened at work as being a result of the country's culture. In this case there was mentioning of sexism, more specifically machismo, but the participant emphasized that she was not the victim, but rather, someone else in her workplace. Other participants mentioned their organizational culture and the positive or negative impact it had on individual behavior at work.

When asked openly and specifically about discrimination, several participants reported experiencing or witnessing something similar to prejudice at work, even if covert in some cases. Interestingly enough, these women shared something in common - they were 40 years old and above and seemed more comfortable to discuss this topic.

Table I: Gender issues perceived and experienced at work

\begin{tabular}{|c|c|}
\hline Participant & Gender issues perceived and experienced at work \\
\hline Part & $\begin{array}{l}\text { "Certain behaviors towards women are not accepted here - our } \\
\text { organizational culture is that men and women are equal." }\end{array}$ \\
\hline Part & $\begin{array}{l}\text { "I notice a difference, but it is very hard to detect. This is an energy } \\
\text { company and there are a lot of men around. They respect me, but I } \\
\text { see it." }\end{array}$ \\
\hline Par & $\begin{array}{l}\text { "I believe our society still has elements of machismo. Women here in } \\
\text { Brazil are still seen as inferior, even if it is covert. What happens at } \\
\text { work reflects this. Again, it's not that I experience it, not me, I don't. } \\
\text { But I think my company does not do a good job at stopping this." }\end{array}$ \\
\hline Participant 8 & "Things here are pretty equal." \\
\hline Participant 10 & "I feel I have a voice just like men do." \\
\hline Participant 11 & $\begin{array}{l}\text { "Yes, I guess there is some prejudice. Actually, I'm not sure I would } \\
\text { call it prejudice... It's just a different behavior, different } \\
\text { expectations." }\end{array}$ \\
\hline Participant 16 & "Not really, everyone has the same opportunities here." \\
\hline Participant 21 & $\begin{array}{l}\text { There is definitely a difference in how men and women are seen and } \\
\text { treated here. I think it's due to the corporate culture. They seem to }\end{array}$ \\
\hline
\end{tabular}




\begin{tabular}{|l|l|}
\hline & $\begin{array}{l}\text { value men more, I think - I feel [...] Not that anything happened to } \\
\text { me..." }\end{array}$ \\
\hline
\end{tabular}

The categories on Table 2 involved HR practices, particularly hiring practices and whether there was favoritism regarding men over women. The themes that emerged dealt with (a) supervisor pressure, (b) male-dominated jobs, (c) favoritism towards men (d) double-sword policies (such as maternity leave), and (e) family interference with work.

Most respondents reported situations where skewed hiring practices took place. More specifically, they indicated that male candidates were given preference and that they were obliged to follow their manager's or supervisor's orders. In addition, discussions signaled an overall preference for male workers in instances of promotions and opportunities for supervisor roles as indicated in the excerpts below.

Furthermore, discourse surrounding working women seemed to take into consideration organizational benefits targeted at women such as maternity leave and the many facets of the domestic sphere that may interfere with work. There were no references to the quality of women's work, but rather on external influences such as family and children.

\section{Table 2: Human resources practices}

\begin{tabular}{|l|l|}
\hline Participant & Human resources practices \\
\hline Participant 5 & $\begin{array}{l}\text { "I work in HR so I see a difference in the number of men and women } \\
\text { hired for important jobs. At my company, in some roles they always } \\
\text { prefer to hire men. What can I do about that? “ }\end{array}$ \\
\hline Participant 7 & $\begin{array}{l}\text { "In my area of work, women are not able to gain space. There are a lot } \\
\text { of men, it's an industrial area, so usually women stay away. For her to } \\
\text { impress, she needs to be very tough. I've tried to get more women there, } \\
\text { but it hasn't worked. Now I don't even interview them - I fill the } \\
\text { positions with men." }\end{array}$ \\
\hline Participant & $\begin{array}{l}\text { "I see women get hired... sometimes promoted... but it's usually more } \\
\text { entry-level or low-level managers. Maybe middle managers. The top is } \\
\text { usually all male. I believe it's a reflection of our society; things are }\end{array}$ \\
\hline
\end{tabular}




\begin{tabular}{|c|c|}
\hline & $\begin{array}{l}\text { changing but slowly. We have a lot of work to do, but sometimes I'm } \\
\text { discouraged, especially when I feel unrecognized at work." }\end{array}$ \\
\hline $\begin{array}{l}\text { Participant } \\
19\end{array}$ & $\begin{array}{l}\text { "The manager tells me she needs a person who will stay and I wonder } \\
\text { why she is saying that. She is a woman after all. She tells me that her } \\
\text { last hire was a woman and that after one year and two months that } \\
\text { woman got pregnant. The employee had a complicated pregnancy so } \\
\text { she had to stay away for long periods of time...so she wasn't } \\
\text { contributing all she could - not only because of the pregnancy, but also } \\
\text { because of emotional issues. So now this female manager only wants } \\
\text { to hire men." }\end{array}$ \\
\hline $\begin{array}{l}\text { Participant } \\
22\end{array}$ & $\begin{array}{l}\text { "With women we know that there are all those other things... Kids, } \\
\text { parents, family - a lot of stuff outside work to manage. That impacts } \\
\text { how available they are perceived by the boss" }\end{array}$ \\
\hline $\begin{array}{l}\text { Participant } \\
25\end{array}$ & $\begin{array}{l}\text { "I have heard a lot of women say they prefer male supervisors. I guess } \\
\text { there is less emotion with them - they are more pragmatic, so they are } \\
\text { easier to work with" }\end{array}$ \\
\hline
\end{tabular}

When examining the experience of being a woman at work the main themes identified included (a) the unrealistic expectations faced by women, (b) the multiple roles held by women at home and at work, (c) the perception that women are emotional beings, less competitive and focused on harmony and their home life, and (d) investment in professional and personal development. Some of the responses emphasized the fact that women face what they interpret as unrealistic and rather utopic expectations. Several participants highlighted the accumulation of roles faced by women, often perceived as conflicting roles. However, they noted the way women were increasingly investing in their education and career.

The accounts described by women also signaled that they tend not to engage in competitive behavior in the workplace as often as men do. According to some of the respondents, certain work roles require women to be tough, like men - which is a challenge. As per their own discourse, women are supposed to be feminine - an impression shared by many. The overall feeling, perpetuated by the women themselves, was that women do have several roles, and although they can be excellent professionals, they have a home and a family that need attention. This seemed to be a recurrent theme 
in other topics as well. Some of the respondents discussed the pressures they suffer because of these expectations, but there was not a clear indication that the women wanted to change the status quo. In some situations, women seemed to repeat and perpetuate stereotypical views to help explain why they may not progress as men do in their careers.

\section{Table 3: The experience of being a working woman}

\begin{tabular}{|c|c|}
\hline Participant & The experience of being a working woman \\
\hline 1 & $\begin{array}{l}\text { "I try to deal with it the best that I can. I've changed jobs before so I } \\
\text { can spend more time with my kids. But my career is important to } \\
\text { me...My last company helped pay for an MBA and I think that will } \\
\text { help me. Men still have it easier, not just at work." }\end{array}$ \\
\hline Part & $\begin{array}{l}\text { "Women do a ton of things at the same time. They have kids, they take } \\
\text { care of the house and they still go get post-graduate degrees. Men go } \\
\text { play soccer after work. OK, they work similar hours, but women will } \\
\text { invest in their career and in bettering themselves.... Men play to win; } \\
\text { they are always playing, competing. Women tend to focus on what } \\
\text { completes them; they are not out there to climb the ladder constantly. } \\
\text { Men, no, they are not there without a plan." }\end{array}$ \\
\hline Participant 8 & “[...] women are emotional beings, even at work..." \\
\hline $\begin{array}{l}\text { Participant } \\
19\end{array}$ & $\begin{array}{l}\text { "The western capitalist culture - this American model - wants a wonder } \\
\text { woman. You have to be a beautiful woman, with a beautiful family and } \\
\text { be successful. It is like a margarine commercial!" }\end{array}$ \\
\hline $\begin{array}{l}\text { Participant } \\
26\end{array}$ & $\begin{array}{l}\text { "...probably a combination of factors. I read it once that women have } \\
\text { to prove themselves at work before they will be recognized with a } \\
\text { promotion or praise, and for men, it happens before they need to prove } \\
\text { it. It's like they are given a chance. The women here are phenomenal, } \\
\text { some men are good too, but there are mediocre ones. They get noticed } \\
\text { more too. It seems to be the way things are - an appearance. I would } \\
\text { say that there are women behind a lot of initiatives - they just don't } \\
\text { show off as much." }\end{array}$ \\
\hline
\end{tabular}


Finally, the last topic deals with the experience of working women at home. Responses often varied based on marital status and presence of children. The main themes involved: (a) stress from multiple roles, (b) support from spouse, family or friends, (c) disappointment with single life and childlessness, and (d) importance of life outside of work.

Some participants were married or lived with a partner. They considered their lives at home often as they talked about their roles as mothers and/or wives. When respondents mentioned husbands or partners, they often used the verb help, confirming a tendency or habit to assign primary responsibilities over household tasks to women. Single women described their life in more negative terms emphasizing the aspects of not being married and not having children as shortcomings. They tended to over-explain the amount of free time they have and how they were able to fill the void with other activities. Overall, the discourse surrounding the different domains of work and life was associated with choice, but also with fate.

Table 4: The experience of being a working woman at home

\begin{tabular}{|l|l|}
\hline Participant & The experience of being a working woman at home \\
\hline Participant 5 & $\begin{array}{l}\text { "I think it's too late for me to have children. I know other women here } \\
\text { who are trying and they are not having any luck. I think I can fulfill this } \\
\text { need with my boyfriend's children. But it's difficult to get to that } \\
\text { realization - that it's not going to happen for me." }\end{array}$ \\
\hline Participant 6 & $\begin{array}{l}\text { "My husband is from a different state, so here it's just the two of us and } \\
\text { our children. Our life is pretty much work and doing stuff with the } \\
\text { children. And sports too - we both like it and we want to stay fit." }\end{array}$ \\
\hline Participant 9 & $\begin{array}{l}\text { "I stay at work when I need to. But I also spent a lot of time with my } \\
\text { visit. I make sure it's not all about work." }\end{array}$ \\
\hline Participant & $\begin{array}{l}\text { "I end up having a lot of free time... I am not married and I do not have } \\
\text { kids... I guess it didn't happen that I was with the right person at the } \\
\text { right time. Either they weren't right for me or I wasn't right for them... } \\
\text { But I exercise... I like to be doing something all the time, so I go see }\end{array}$ \\
\hline
\end{tabular}




\begin{tabular}{|l|l|}
\hline \multirow{2}{*}{$\begin{array}{l}\text { Participant } \\
20\end{array}$} & $\begin{array}{l}\text { my family and spend time with them. Or friends... I stay busy. And... } \\
\text { I see so many couples breaking up anyway. Maybe I'm better off." } \\
\text { don't know what I would do without him. I'm lucky. I do get stressed } \\
\text { out about work and he helps me with that too - we talk through things" }\end{array}$ \\
\hline $\begin{array}{l}\text { Participant } \\
\text { "At home I try not to think about work, but it is part of who I am, I'm } \\
\text { not sure everyone gets that. I do think at some point I had given up on } \\
\text { a few things in my life such as my own family. But I've done the } \\
\text { opposite too." }\end{array}$ \\
\hline
\end{tabular}

\section{Discussion}

Despite significant changes in the attitudes towards women in Brazil and abroad, one has to wonder whether any real progress is being made towards gender equality in the lives of professional women in Brazil. Our research indicates that work is still organized along gender lines, and that roles are very traditional despite current global trends and census findings. This is not a discovery that is exclusive to Brazil. Studies conducted in countries with traditional gender roles such as Turkey (e.g., Turk et al., 2013), and India (e.g., Wang and McLean, 2016) have found similar contradictions in gender dynamics at the workplace.

Overall, the most surprising finding in the Brazilian context involved how most women rejected the idea that they were victims of inequality, while utilizing a discourse that seemed to perpetuate differences. When women did discuss having witnessed a situation of discrimination, they described it as taking place with a third person - another woman. A possible explanation for this behavior may be a need for a coping mechanism or for conflict-avoidance, which are characteristics of the Brazilian culture. Many Asian cultures behave in that manner because being passive is preferable to taking action for the preservation of relationships (Noh et al., 1999). Brazilians often demonstrate similar behaviors as they place high value on relationships (de Almeida, 2013; Souza, 2007).

In other words, professional women in Brazil may want to be seen as professionals and not victims. Being perceived as a victim may be understood as a sign of weakness or the acknowledgment of the gender stereotype of the emotional non-rational female. Another explanation could involve how women deal with the inherent contradictions and 
ambivalence that socially-constructed gender roles impose on the way they perceive themselves at work. From an early age, socialization processes determine roles for men and women based on the values, attitudes, and behaviors that are expected from them (Olivas-Lujan et al., 2009).

Prior research supports the notion that successful businesswomen in Latin America do not tend to associate their self-image with discrimination (Maxfield, 2005). However, they do acknowledge the effect machismo has had on women accessing upperlevel positions (Cárdenas et al., 2014). Women, in all hierarchical levels, tend to consider work-family issues as a key limiting factor to their career progression, mainly due to the way work and personal life roles overlap (Cárdenas et al., 2014; Maxfield, 2005). Only those in the highest corporate levels tend to find that discrimination and gender stereotypes are the main obstacle to career success, which is supported by research on Latin American female business executives (Cárdenas et al., 2014).

It is important to note that the impact of family was mentioned several times during the interviews. Indeed, it was expected that the family domain would be intertwined with the work domain for most females. The majority of organizations did not seem to provide enough support through policies and HR. This is corroborated by research in Brazil which suggests that HR is mainly operational, and much of what is done is informally arranged between employee and supervisor (Coda and Falcone, 2004; Tanure et al., 2010).

\section{Conclusion}

The goal of the present study was to examine the experiences of professional women in a developing country context with a history of ingrained gender inequality. From the standpoint of women as individuals, the expectation that women will continue to fulfill the roles traditionally destined to them (through marriage and motherhood) is reinforced by Brazilian society and women act as agents who uphold rather than defy these roles - a self-fulfilling prophecy. The interviews show a combination of acceptance of the status quo with some hints of action, such as investments in career development, job changes and so on. Promoting change would require a new individual, and subsequently collective mindset, since inequality is not an individual issue but part of a broader context. 
From the standpoint of both multinationals and domestic organizations, this study signals some potential pathways for improvement. First, additional research needs to be conducted on organizations operating in Brazil to better understand their diversity discourse and practice. Thus, a journey towards inclusion should be initiated with the understanding that it entails more than rhetoric. In addition, organizations should acknowledge their pivotal role in changing the status quo by adopting a proactive role towards equality. Organizational change must be supported by HR, who should take a strategic rather than operational role to guarantee that all the processes within the organization support an equal environment. The current political and economic climate can be seen as an opportunity for organizations to step in as a series of governmentsponsored rights and policies are under threat.

From a wider societal perspective, it is necessary to understand the interdependence of the various factors and actors; i.e. economic, political, legal and cultural factors; as well as individuals, organizations and all institutions. All factors and actors should contribute to foster an environment that stimulates a virtuous cycle towards the mitigation of gender discrimination and all kinds of inequality, by means of individual engagement; organizational initiatives and policies that truly reflect equality values; and institutional commitment to achieving equality. Such a complex scenario would also benefit from more research addressing gender issues combined with work-life from a quantitative perspective to test whether our findings are indeed representative of the larger Brazilian society. Since Brazil demonstrates an idealized national ethos that promises equality, a combination of qualitative and quantitative research would be ideal to uncover what lies beneath.

Finally, this study hoped to contribute to the broader understanding of gender in developing country contexts. It did so by expanding on the knowledge foundation that includes the culturally-based concepts of machismo and marianismo and the feminist perspective that posits the ingrained nature of gender inequality in society. As a result, we found that despite global trends, it is possible to uncover idiosyncrasies in terms of gender, with traditional gender roles quite present simultaneously with equality discourses. Future research may benefit from including aspects of gender role analysis to identify traditional or egalitarian tendencies while comparing discourse to practice. 


\section{Limitations of this study}

The study suffers from several limitations. First, this is a qualitative study and, as such, it is not generalizable to the wider population. In addition, this study focused on metropolitan regions of São Paulo and Rio de Janeiro. Future studies should include other regions in Brazil and address a larger section of the population. Finally, we understand that the focus solely on gender discrimination oversimplifies the complexity of inequality studies (Ozbilgin et al., 2011), which should consider other categories, such as race and class (together the 'interlocking systems of oppression') (Collins, 2002, p. 225). 


\section{REFERENCES:}

Acker, J. (2006). "Inequality regimes: Gender, class, and race in organizations". Gender \& Society. Vol. 20 No. 4, pp. 441-464.

Agócs, C. and Burr, C. (1996). "Employment equity, affirmative action and managing diversity: assessing the differences". International Journal of Manpower, Vol. 17 No. $4 / 5$, pp. 30-45.

Araújo, A., and Lombardi, M. (2013). "Trabalho informal, gênero e raça no Brasil no início do século XXI". Cadernos de Pesquisa Vol. 43, No. 149 pp. 452-477.

Baldwin, J. and De Souza, E. (2001). "Modelo de María and machismo: The social construction of gender in Brazil". Revista Interamericana de Psicologia, Vol. 35 No. 1, pp. 9-29.

Barcinski, M., Capra-Ramos, C., Weber, J. L., and Dartora, T. (2013). "O Marianismo e a vitimização de mulheres encarceradas: formas alternativas de exercício do poder feminino". Ex aequo, Vol. 28, pp. 87-100.

Bardoel, E. A. (2016). "Work-life management tensions in multinational enterprises (MNEs)". The International Journal of Human Resource Management, Vol. 27, No. 15, pp. 1681-1709.

Barros, R., Fox, L., and Mendonca, R. (1997). "Female-headed households, poverty, and the welfare of children in urban Brazil". Economic Development and Cultural Change, Vol. 45, No. 2, pp. 231-257.

Beede, D. N., Julian, T. A., Langdon, D., McKittrick, G., Khan, B., and Doms, M. E. (2011). "Women in STEM: A gender gap to innovation".

Bluhm, D. J., Harman, W., Lee, T. W. and Mitchell, T. R. (2011). Qualitative research in management: A decade of progress. Journal of Management Studies, Vol. 48 No. 8, pp. 1866-1891.

Bonifácio, R., and Ribeiro, E. (2016). "Corrupção e participação política no Brasil: diagnósticos e consequências". Revista Brasileira de Ciência Política, Vol. 20, pp. 7-42. 
Bruschini, M. (2007). "Trabalho e gênero no Brasil nos últimos dez anos". Cadernos de Pesquisa, Vol. 37 No. 132, pp. 537-572.

Burke, R. J., and Vinnicombe, S. (2013). "Introduction: advancing women's careers: a key business issue". S. Vinnicombe, RJ Burke, S. Blake-Beard, \& LL Moore, Handbook of research on promoting women's careers, pp. 1-47.

Cárdenas, M., Eagly, A., Salgado, E., Goode, W., Heller, L., Jaúregui, K., Galarza Quirós, N., Gormaz, N., Bunse, S. and Godoy, M. (2014). "Latin American female business executives: an interesting surprise". Gender in Management: An International Journal, Vol. 29 No. 1, pp. 2-24.

Casper, W. J., Harris, C., Taylor-Bianco, A., and Wayne, J. H. (2011). "Work-family conflict, perceived supervisor support and organizational commitment among Brazilian professionals". Journal of Vocational Behavior, Vol. 79 No. 3, pp. 640-652.

Chaney, E. (1979). "Supermadre: Women in Politics in Latin America". University of Texas Press.

Collins, P. H. (2002). "Black feminist thought: Knowledge, consciousness, and the politics of empowerment". Routledge.

Coda, R., and Falcone, G. F. (2004). "Em busca do significado do trabalho: relato de um estudo qualitativo entre executivos". Revista brasileira de gestão de negócios. Vol. 6, No. 14, pp. 7-18.

Cook, A., and Glass, C. (2014). "Women and top leadership positions: Towards an institutional analysis ". Gender, Work \& Organization, Vol. 21 No. 1, pp. 91-103.

Corrigan, G. (2015). "Is Brazil making progress on inequality. In World Economic Forum." Retrieved from https://www. weforum. org/agenda/2015/09/is-brazilmaking - progress - on- inequality/ Accessed June Vol. 21, pp. 2016.

Cox, T. H. and Blake, S. (1991). "Managing cultural diversity: Implications for organizational competitiveness". The Executive, Vol. 5 No. 3, pp. 45-56.

Crenshaw, K. W. (2010). Twenty years of critical race theory: Looking back to move forward. Connecticut Law Review, Vol. 43 No. 5, pp. 1253-1352. 
Degraff, D. S. and Anker, R. (2015). "Gênero, mercados de trabalho e o trabalho das mulheres". Associação Brasileira de Estudos Populacionais.

Diekman, A. B., Eagly, A. H., Mladinic, A. and Ferreira, M. C. (2005). "Dynamic stereotypes about women and men in Latin America and the United States". Journal of Cross-Cultural Psychology, Vol. 36 No. 2, pp. 209-226.

Eagly, A. H., and Heilman, M. E. (2016). "Gender and leadership: Introduction to the special issue". The Leadership Quarterly, Vol. 3 No. 27, pp. 349-353.

Félix-Ortiz, M., Abreu, J. M., Briano, M. and Bowen, D. (2001). "A critique of machismo measures in psychological research". Advances in Psychology Research, Vol. 3, pp. 6390 .

Ferree, M. M. (1990). "Beyond separate spheres: Feminism and family research". Journal of Marriage and Family. Vol. 52, No. 4, pp. 866.

Fleury, M. T. L. (1999). "The management of culture diversity: lessons from Brazilian companies", Industrial Management \& Data Systems, Vol. 99, No 3, pp. 109-114.

Galbreath, M. (2017). "A new world: Politics in post-Olympics Brazil". Harvard International Review, pp. 14-16.

Gilbert, J. A., Stead, B. A. and Ivancevich, J. M. (1999). "Diversity management: A new organizational paradigm". Journal of Business Ethics, Vol. 21 No. 1, pp. 61-76.

Gonçalves, M. E.; Perez, E. R.; and Wajnman, S. (2016). "Taxas de Participação (Formal e Informal) Feminina no Mercado de Trabalho das Regiões Sudeste e Nordeste: uma análise a partir das PNADs, 1992-2002. " Associação Brasileira de Estudos Populacionais.

Gotsis, G. and Kortezi, Z. (2013). "Ethical paradigms as potential foundations of diversity management initiatives in business organizations". Journal of Organizational Change Management, Vol. 26 No. 6, pp. 948-976.

Hausmann, R., Tyson, L. and Zahidi, S. (2014). "The global gender gap report 2013".

Heinrich, A. (2012). "Foreign reporting in the sphere of network journalism". Journalism Practice, Vol. 6 No. 5-6, pp. 766-775. 
Holden, N., Michailova, S. and Tietze, S. (2015), "The Routledge Companion to Cross-Cultural Management ". Routledge, New York, NY.

Hsieh, H.-F. and Shannon, S. E. (2005). "Three approaches to qualitative content analysis". Qualitative Health Research, Vol. 15 No. 9, pp. 1277-1288.

Human Development Report (2016). "Work For Human Development 2016"

Instituto Brasileiro de Geografia e Estatística (2010). "Características da população e dos domicílios".

Instituto Brasileiro de Geografia e Estatística (2016). "Características da população e dos domicílios."

Instituto de Pesquisa Econômica Aplicada (2016). "Retrato das Desigualdades de Gênero e Raça.".

Ivancevich, J. M. and Gilbert, J. A. (2000). "Diversity management time for a new approach". Public Personnel Management, Vol. 29 No. 1, pp. 75-92.

Jabbour, C. J. C., de Sousa Jabbour, A. B. L., Govindan, K., De Freitas, T. P., Soubihia, D. F., Kannan, D., and Latan, H. (2016). Barriers to the adoption of green operational practices at Brazilian companies: effects on green and operational performance. International Journal of Production Research, Vol. 54 Iss. 10, pp. 3042-3058.

Joshi, A., Son, J., and Roh, H. (2015). "When can women close the gap? A meta-analytic test of sex differences in performance and rewards". Academy of Management Journal, Vol.58, pp. 1516-1545.

Jabbour, J.C., Serotini, F G., Henrique, J. C. O., Carlos, J. M. and Aparecida, R. G. B. (2011). "Diversity management: challenges, benefits, and the role of human resource management in Brazilian organizations". Equality, Diversity and Inclusion: An International Journal, Vol. 30 No. 1, pp. 58-74.

Lazzaretti, K., Kleinübing, C., Parodi, S. O. C. and Marcon, R. (2013). "Gender diversity in the boards of directors of Brazilian businesses". Gender in Management: An International Journal, Vol. 28 No. 2, pp. 94-110.

Lee, T. W. (1999). "Using qualitative methods in organizational research". Sage Publications. 
Madsen, S. R., Madsen, S. R., Scribner, R. T., and Scribner, R. T. (2017). "A perspective on gender in management: The need for strategic cross-cultural scholarship on women in management and leadership". Cross Cultural \& Strategic Management, Vol. 24 No. 2, pp. 231-250.

Margolis, M. L., Bezerra, M. E. and Fox, J. M. (2001). "Countries and their cultures: Brazil". MacMillan.

Maxfield, S. (2005). "Modifying best practices in women's advancement for the Latin American context". Women in Management Review, Vol. 20 No. 4, pp. 249-261.

Miles, M. B. and Huberman, A. M. (1994). Qualitative data analysis: An expanded sourcebook. Sage Publications.

Ministério de Trabalho e Emprego (2016).

Mirandé, A. (1985). "The Chicano experience: An alternative perspective". Notre Dame, University of Notre Dame Press.

Moreira, L.A. (2016). "Direito e gênero: a contribuição feminista para a formação política das mulheres no processo de (re) democratização brasileiro". Revista Gênero \& Direito, Vol. 5 No. 1, pp. 217-255.

Moreno, C. L. (2007). "The relationship between culture, gender, structural factors, abuse, trauma, and HIV/AIDS for Latinas". Qualitative health research. Vol. 17, No. 3, pp. 340-352.

Morse, J. M. and Field, P.-A. (1995). "Nursing research: The application of qualitative approaches". Nelson Thornes.

Narvaz, M., and Koller, S. H. (2006). "Famílias e patriarcado: da prescrição normativa à subversão criativa". Psicologia \& sociedade. Vol. 18, No. 1, pp. 49-55.

Nkomo, S. M. (2013). "Inclusion: Old Wine in New Bottles?". Diversity at work: The Practice of Inclusion, (eds B. M. Ferdman and B. R. Deane), John Wiley \& Sons. pp. 580592.

Noh, S., Beiser, M., Kaspar, V., Hou, F., and Rummens, J. (1999). "Perceived racial discrimination, depression, and coping: A study of Southeast Asian refugees in Canada". Journal of health and social behavior, pp. 193-207. 
Olinto, G.; and De Oliveira, Z. L. C. (2016). "Gênero e trabalho precário no Brasil urbano: perspectivas de mudança". Associação Brasileira de Estudos Populacionais.

Olivas-Luján, M., Monserrat, S., Ruiz-Gutierrez, J., Greenwood, R., Madero-Gomez, S. and Murphy, E. F. S. (2009)," Values and Attitudes Towards Women in Argentina, Brazil, Colombia, and Mexico". Employee Relations, Vol. 31 No. 3, pp. 227-244.

Oswick, C. and Noon, M. (2014). "Discourses of diversity, equality and inclusion: trenchant formulations or transient fashions?". British Journal of Management, Vol. 25 No. 1, pp. 23-39.

Ozbilgin, M. F., Beauregard, T. A., Tatli, A. and Bell, M. P. (2011). "Work-life, diversity and intersectionality: a critical review and research agenda". International Journal of Management Reviews, Vol. 13 No. 2, pp. 177-198.

Pew Research Center (2010) "Global Attitudes Project: Brazilians upbeat about their country, despite its problems".

Risman, B. J. (2004). "Gender as a social structure: Theory wrestling with activism". Gender \& Society. Vol. 18, No. 4, pp. 429-450.

Rubin, H. J. and Rubin, I. S. (2011). "Qualitative interviewing: The art of hearing data". Sage Publications.

Sheng, H. H., and Carrera Júnior, J. M. (2016). "Leading brazilian multinational enterprises: trends in an era of significant uncertainties and challenges".

Sorj, B., Fontes, A., Carusi, D. and Qintaes, G. (2004). "Reconciling work and family: Issues and policies in Brazil". International Labour Office Geneva.

Souza, R. L. D. (2007). "The roots and the "Cordial Man's" future according to Sérgio Buarque de Holanda". Caderno CRH, Vol. 20 No. 50, pp. 343-353.

Tanure, B., Evans, P. and Cançado, V. L. (2010). "The four faces of HR: analyzing the performance of Human Resource management in Brazilian companies". Revista de Administração Contemporânea, Vol. 14 No. 4, pp. 594-614.

Tatli, A. (2010). "Discourses and practices of diversity management in the UK". International Handbook on Diversity Management at Work: Country Perspectives on Diversity and Equal Treatment. London: Edward Elgar. 
Tesch, R. (1990). "Qualitative analysis: Analysis types and software tools". Falmer Press, London.

Theodorakopoulos, N. and Budhwar, P. (2015). "Guest Editors' Introduction: Diversity and Inclusion in Different Work Settings: Emerging Patterns, Challenges, and Research Agenda". Human Resource Management, Vol. 54 No. 2, pp. 177-197.

Thomas, D. A. and Ely, R. J. (1996). "Making differences matter". Harvard Business Review, Vol. 74 No. 5, pp. 79-90.

Torres, J. B., Solberg, V. S. H., and Carlstrom, A. H. (2002). "The myth of sameness among Latino men and their machismo". American Journal of Orthopsychiatry. Vol. 72, No. 2, pp. 163.

Turk, M., Davas, A., Tanik, F. A., and Montgomery, A. J. (2014). "Organizational stressors, work-family interface and the role of gender in the hospital: Experiences from Turkey.” British Journal of Health Psychology, Vol. 19 No. 2, pp. 442-458.

Vasconcellos, V. C., Borges-Andrade, J. E., Porto, J. B. and Fonseca, A. M. D. O. (2016). "Carreira nas organizações: revisão da produção brasileira no âmbito do microcomportamento organizacional". Revista Psicologia Organizações e Trabalho, Vol. 16 No. 1, pp. 73-87.

Wang, J., and McLean, G. N. (2016). "Promoting diversity in India: where do we go from here?”. Advances in Developing Human Resources, Vol. 18 No.1, pp. 102-113.

Wyrod, R. (2008). “Between women's rights and men's authority: Masculinity and shifting discourses of gender difference in urban Uganda." Gender \& Society, Vol. 22 No. 6, pp. 799-823.

Zanoni, P., Janssens, M., Benschop, Y. and Nkomo, S. M. (2010). "Unpacking diversity, grasping inequality: Rethinking difference through critical perspectives." Organization. Vol. 1 No. 1, pp. 9-29. 